\title{
PENGARUH KUALITAS PRODUK DAN PROMOSI TERHADAP KEPUTUSAN PEMBELIAN PELANGGAN PRODUK PT. SAYAP MAS UTAMA
}

\author{
Clara Putri Claudy 1) \\ 1) Mahasiswa Program Studi Manajemen FE UNKRIS \\ Donny Dharmawan 2) \\ 2) Dosen Program Studi Manajemen FE UNKRIS \\ Alamat: Kampus UNKRIS, Jatiwaringin Jakarta Timur \\ Email : donnydh28@gmail.com
}

\begin{abstract}
To describe product quality, promotion and customer purchasing decision products of PT. Sayap Mas Utama, and to analysis the effect of quality products on customer ourchasing decisions PT. Sayap Mas Utama. This study uses data collection methods. Using a questionnaire, the data analysis method used is descriptive analysis, simple liner regression. The result of the study show that promotion positive and significant effect on customer satisfaction the quality of service has a positive effect and significant to customer satisfaction PT. Sayap Mas Utama.
\end{abstract}

Keywords: Product quality, promotion and purchasing decision

\section{PENDAHULUAN}

Perkembangan dunia saat ini berjalan dengan pesat, yang menciptakan suatu persaingan yang semakin ketat. Hal ini yang menuntut produsen untuk lebih peka, kritis dan kreatif terhadap perubahan yang ada, baik politik, sosial budaya, dan ekonomi. Syarat yang harus dipenuhi oleh suatu perusahaan agar dapat mencapai sukses dalam persaingan adalah berusaha mencapai tujuan untuk menciptakan dan mempertahankan pelanggan. Agar tujuan tersebut tercapai, maka setiap perusahaan harus berupaya menghasilkan dan menyampaikan barang dan jasa yang diinginkan konsumen dengan harga yang pantas. Dengan demikian, setiap perusahaan harus mampu memahami kelangsungan hidup perusahaan tersebut sebagai organisasi yang berusaha memenuhi kebutuhan dan keinginan para konsumen sangat tergantung pada perilaku konsumennya.
Saat ini, perkembangan jumlah penduduk yang cukup pesat serta beragamnya aktivitas kerja setiap orang memungkinkan segala aktivitas tersebut harus dilakukan secara cepat. Agar orang dapat melakukan pekerjaan secara cepat, dibutuhkan sarana pendukung, seperti sarana transportasi. Transportasi merupakan alat yang berguna untuk memindahkan barang atau orang dalam kuantitas tertentu, ke suatu tempat tertentu, dalam jangka waktu tertentu (Tjiptono,1997).

Mengingat

pentingnya pengendalian penjualan yang merupakan aktivitas terpenting bagi perusahaan yang bergerak di bidang consumer goods, peneliti melakukan penelitian di PT.Sayap Mas Utama, khususnya pada bagian penjualan. Pada bagian penjualan ini merupakan bagian yang paling penting karena perusahaan ini tetap mempertahankan bisnis utamanya dalam 
penjualan sabun colek (toiletries), yang kini merambah ke berbagai bidang usaha. Oleh karena itu, pengendalian terhadap aktivitas penjualan merupakan suatu hal yang tidak dapat diabaikan karena merupakan sumber utama pendapatan dan penentu di dalam kelangsungan hidup perusahaan. Karena itu peneliti merasa tertarik untuk meneliti PT. Sayap Mas Utama yang lebih dari 30 tahun lamanya dapat mempertahankan image atau citra perusahaan dengan melakukan pengendalian penjualan, sehingga produk tersebut dapat di terima oleh masyarakat dan dapat meraih sukses hingga saat ini.

Tabel 1: Volume Penjualan

\begin{tabular}{clcc}
\hline TAHUN & JENIS BARANG & $\begin{array}{c}\text { VOLUME } \\
\text { PENJUALAN }\end{array}$ & PERSENTASE \\
\hline \multirow{2}{*}{2018} & LIQUID SOAP & 373.690 & $38 \%$ \\
& BAR SOAP & 138.890 & $22 \%$ \\
& SHAMPOO & 14.272 & $15 \%$ \\
& FLOOR CLEANER & 46.923 & $21 \%$ \\
& LIQUID SOAP & 472.830 & $27 \%$ \\
\multirow{2}{*}{2019} & BAR SOAP & 142.170 & $2 \%$ \\
& SHAMPOO & 13.624 & $-5 \%$ \\
& FLOOR CLEANER & 39.957 & $-15 \%$ \\
& LIQUID SOAP & 57.577 & $-88 \%$ \\
2020 & BAR SOAP & 13.763 & $-90 \%$ \\
& SHAMPOO & 9.209 & $-32 \%$ \\
& FLOOR CLEANER & 41.110 & $3 \%$ \\
\hline
\end{tabular}

Sumber : PT. Sayap Mas Utama ( Wings)

Dari tabel 1, dapat dilihat tingkat penjualan PT. Sayap Mas Utama dari tahun ketahun tidak stabil. Dari tahun 2018 ke 2019 mengalami kenaikan pada produk liquid soap dan bar soap. Tetapi produk Shampoo dan Floor Cleaner mengalami penurunan. Begitu pula pada tahun 2020 hanya Floor Cleaner yang mengalami kenaikan penjualan dan sisanya menurun.

\section{LANDASAN TEORI}

\section{Keputusan Pembelian}

Keputusan Pembelian Konsumen merupakan sebuah tindakan yang dilakukan konsumen untuk membeli suatu produk. Setiap produsen pasti menjalankan berbagai strategi agar konsumen memutuskan untuk membeli produknya. Menurut Kotler (2003), keputusan pembelian adalah tindakan dari konsumen untuk mau membeli atau tidak terhadap produk. Dari berbagai faktor yang mempengaruhi konsumen dalam melakukan pembelian suatu produk atau jasa, biasanya konsumen selalu mempertimbangkan kualitas, harga dan produk yang sudah dikenal oleh masyarakat. Menurut Swastha dan Handoko (2011) berpendapat bahwa lima peran individu dalam sebuah keputusan membeli, yaitu: 1). Pengambilan inisiatif (initiator); Individu yang mempunyai inisiatif pembelian barang tertentu atau yang mempunyai kebutuhan atau keinginan tetapi tidak mempunyai wewenang untuk melakukan sendiri. 2). Orang yang mempengaruhi (influencer); Individu yang mempengaruhi keputusan untuk membeli baik secara sengaja maupun tidak sengaja. 3). Pembuat keputusan (decider); Individu yang memutuskan apakah akan membeli atau tidak, apa yang akan dibeli, bagaimana 
membelinya, kapan dan dimana membelinya. 4). Pembeli (buyer); Individu yang melakukan pembelian yang sebenarnya. 5). Pemakai (user); Individu yang menikmati atau memakai produk atau jasa yang dibeli.

Menurut Kotler (2003) terdapat empat faktor yang mempengaruhi keputusan pembelian diantaranya: 1). Faktor Budaya; Budaya, sub budaya, dan kelas sosial sangat penting bagi perilaku pembelian. Budaya merupakan penentu keinginan dan perilaku paling dasar. Anak-anak yang sedang tumbuh akan mendapatkan seperangkat nilai, persepsi, preferensi, dan perilaku dari keluarga dan lembaga-lembaga penting lainnya. Contonhya pada anak-anak yang dibesarkan di Amerika Serikat sangat terpengaruh dengan nilai-nilai sebagai berikut: prestasi, aktivitas, efisiensi, kemajuan, kenikmatan materi, individualisme, kebebasan, humanisme, dan berjiwa muda. Masing-masing subbudaya terdiri dari sejumlah subbudaya yang lebih menampakkan identifikasi dan sosialisasi khusus bagi para anggotanya seperti kebangsaan, agama, kelompok, ras, dan wilayah geografis. Pada dasaranya dalam sebuah tatanan kehidupan dalam bermasyarakat terdapat sebuah tingkatan (strata) sosial. Tingkatan sosial tersebut dapat berbentuk sebuah sistem kasta yang mencerminkan sebuah kelas sosial yang relatif homogen dan permanen yang tersusun secara hirarkis dan para anggotanya menganut nilai, minat dan perilaku yang serupa. Kelas sosial tidak hanya mencerminkan penghasilan, tetapi juga indikator lain seperti pekerjaan, pendidikan, perilaku dalam berbusana, cara bicara, rekreasi dan lain-lainya. 2). Fakor Sosial; Faktor sosial yang mempengaruhi keputusan pembelian diantaranya: a). Kelompok acuan; Kelompok acuan dalam perilaku pembelian konsumen dapat diartikan sebagai kelompok yang yang dapat memberikan pengaruh secara langsung atau tidak langsung terhadap sikap atau perilaku seseorang tersebut. Kelompok ini biasanya disebut dengan kelompok keanggotaan, yaitu sebuah kelompok yang dapat memberikan pengaruh secara langsung terhadap seseorang. Adapun anggota kelompok ini biasanya merupakan anggota dari kelompok primer seperti keluarga, teman, tetangga dan rekan kerja yang berinteraksi dengan secara langsung dan terus menerus dalam keadaan yang informal. Tidak hanya kelompok primer, kelompok sekunder yang biasanya terdiri dari kelompok keagamaan, profesi dan asosiasi perdagangan juga dapat disebut sebagai kelompok keanggotaan. b). Keluarga; Dalam sebuah organisasi pembelian konsumen, keluarga dibedakan menjadi dua bagian. Pertama keluarga yang dikenal dengan istilah keluarg orientas. Keluarga jenis ini terdiri dari orang tua dan saudara kandung seseorang yang dapat memberikan orientasi agam, politik dan ekonomi serta ambisi pribadi, harga diri dan cinta. Kedua, keluarga yang terdiri dari pasangan dan jumlah anak yang dimiliki seseorang. Keluarga jenis ini biasa dikenal dengan keluarga prokreasi. c). Peran dan status; Hal selanjutnya yang dapat menjadi faktor sosial yang dapat mempengaruhi perilaku pembelian seseorang adalah peran dan status mereka di dalam masyarakat. Semakin tinggi peran seseorang didalam sebuah organisasi maka akan semakin tinggi pula status mereka dalam organisasi tersebut dan secara langsung dapat berdampak pada perilaku pembeliannya. Contoh seorang direktur di sebuah perusahaan tentunya memiliki status yang lebih tinggi dibandingkan dengan seorang supervisor, begitu pula dalam perilaku pembeliannya. Tentunya, seorang direktur perusahaan akan melakukan pembelian terhadap merek-merek yang berharga lebih mahal dibandingkan dengan merek lainnya. 3). Faktor Pribadi; Keputusan pembelian juga dapat dipengaruhi oleh 
karakterisitik pribadi diantaranya: a). Usia dan siklus hidup keluarga; Orang membeli barang dan jasa yang berbeda-beda sepanjang hidupnya yang dimana setiap kegiatan konsumsi ini dipengaruhi oleh siklus hidup keluarga. b). Pekerjaan dan lingkungan ekonomi; Pekerjaan dan lingkungan ekonomi seseorang dapat mempengaruhi pola konsumsinya. Cotohnya, direktur perusahaan akan membeli pakaian yang mahal, perjalanan dengan pesawat udara, keanggotaan di klub khusus, dan membeli Produk mewah. Selain itu, biasanya pemilihan produk juga dilakukan berdasarkan oleh keadaan ekonomi seseorang seperti besaran penghasilan yang dimiliki, jumlah tabungan, utang dan sikap terhadap belanja atau menabung. c). Gaya hidup; Gaya hidup dapat di artikan sebagai sebuah pola hidup seseorang yang terungkap dalam aktivitas, minat dan opininya yang terbentuk melalui sebuah kelas sosial, dan pekerjaan. Tetapi, kelas sosial dan pekerjaan yang sama tidak menjamin munculnya sebuah gaya hidup yang sama. Melihat hal ini sebagai sebuah peluang dalam kegiatan pemasaran, banyak pemasar yang mengarahkan merek mereka kepada gaya hidup seseorang. Contohnya, perusahaan telepon seluler berbagai merek berlomba-lomba menjadikan produknya sesuai dengan berbagai gaya hidup remaja yang modern dan dinamis seperti munculnya telepon selular dengan fitur multimedia yang ditujukan untuk kalangan muda yang kegiatan tidak dapat lepas dari berbagai hal multimedia seperti aplikasi pemutar suara, video, kamera dan sebagainya. Atau kalangan bisnis yang menginginkan telepon selular yang dapat menujang berbagai kegiatan bisnis mereka. d). Kepribadian; Setiap orang memiliki berbagai macam karateristik kepribadian yang bebeda-beda yang dapat mempengaruhi aktivitas kegiatan pembeliannya. Kepribadian merupakan ciri bawaan psikologis manusia yang berbeda yang menghasilkan sebuah tanggapan relatif konsiten dan bertahan lama terhadap rangsangan lingkungannya. Kepribadian biasanya digambarkan dengan menggunakan ciri bawaan seperti kepercayaan diri, dominasi, kemampuan bersosialisasi, pertahanan diri dan kemapuan beradaptasi. Kepribadian dapat menjadi variabel yang sangat berguna dalam menganalisis pilihan merek konsumen. Hal ini disebakan karena beberapa kalangan konsumen akan memilih merek yang cocok dengan kepribadiannya. 4). Faktor Psikologis; Faktor psikologis ditentukan oleh empat faktor utama diantaranya: a). Motivasi; Seseorang memiliki banyak kebutuhan pada waktu-waktu tertentu. Beberapa dari kebutuhan tersebut ada yang muncul dari tekanan biologis seperti lapar, haus, dan rasa ketidaknyamanan. Sedangkan beberapa kebutuhan yang lainnya dapat bersifat psikogenesis; yaitu kebutuhan yang berasal dari tekanan psikologis seperti kebutuhan akan pengakuan, penghargaan atau rasa keanggotaan kelompok. Ketika seseorang mengamati sebuah merek, ia akan bereaksi tidak hanya pada kemampuan nyata yang terlihat pada merek tersebut, melainkan juga melihat petunjuk lain yang samar seperti wujud, ukuran, berat, bahan, warna dan nama merek tersebut yang memacu arah pemikiran dan emosi tertentu. Herzerberg mengembangkan teori duafaktor yang membedakan dissastifier (faktor-faktor yang menyebabkan ketidakpuasan) dan satisfier (faktor-faktor yang menyebabkan kepuasan) yang dapat memotivasi kegiatan pembelian konsumen. Ia mencotohkan dalam kegiatan pembelian komputer yang dimana tidak adanya garansi dapat menjadi faktor dissaatisfier tetapi adanya garansi juga tidak menjadi pemuas atau motivator pembelian, karena garansi bukan merupakan sumber kepuasan instrinsik komputer. Melainkan kemudahan penggunaanlah yang dapat 
menjadi satisfier yang dapat memotivasi kegiatan pembelian. b). Persepsi; Persepsi dapat diartikan sebagai sebuah proses yang digunakan individu untuk memilih, mengorganisasi, dan menginterpretasi masukan informasi guna menciptakan sebuah gambaran (Barelson dalam Kotler 2003). Persepsi tidak hanya bergantung pada rangsangan fisik tetapi juga pada rangsangan yang berhubungan dengan lingkungan sekitar dan keadaan individu yang bersangkutan. Setiap produk atau merek memiliki persepsi berbeda pada setiap konsumen. Hal ini dikarenakan ada tiga proses persepsi yaitu : (1). Perhatian selektif; Perhatian selektif dapat diartikan sebagai proses penyaringan atas berbagai informasi yang didapat oleh konsumen. Dalam hal ini para pemasar harus bekerja keras dalam rangka menarik perhatian konsumen dan memberikan sebuah rangsangan nama yang akan diperhatikan orang. Hal ini disebabkan karena orang lebih cenderung memperhatikan rangsangan yang berhubungan dengan kebutuhnnya saat ini, memperhatikan rangsangan yang mereka antisipasi dan lebih memerhatikan rangsangan yang memiliki deviasi besar terhadap ukuran rangsangan normal seperti, orang cenderung akan memperhatikan iklan yang menawarkan potongan dan bonus sebesar Rp 100.000,- ketimbang iklan komputer yang hanya memberikan bonus atau potongan yang bernilai $\mathrm{Rp} 50.000$,(2). Distorsi selektif; Distorsi selektif merupakan proses pembentukan persepsi yang dimana pemasar tidak dapat berbuat banyak terhadap distorsi tersebut. Hal ini karena distorsi selektif merupakan kecenderungan orang untuk mengubah informasi menjadi bermakna pribadi dan menginterpretasikan informasi yang didapat dengan cara yang akan mendukung pra konsepsi konsumen. (3). Ingatan selektif; Orang akan banyak melupakan banyak hal yang mereka pelajari namun cenderung akan senantiasa mengingat informasi yang mendukung pandangan dan keyakinan mereka. Karena adanya ingatan selektif, kita cenderung akan mengingat hal-hal baik yang disebutkan tentang produk yang kita sukai dan melupakan hal-hal baik yang disbutkan tentang produk yang bersaing. c). Pembelajaran; Pembelajaran meliputi perubahan perilaku seseorang yang timbul dari pengalaman. Banyak ahli pemasaran yang yakin bahwa pembelajaran dihasilkan melalui perpaduan kerja antara pendorong, rangsangan, isyarat bertindak, tanggapan dan penguatan. Teori pembelajaran mengajarkan kepada para pemasar bahwa mereka dapat membangung permintaan atas suatu produk dengan mengaitkan pada pendorongnya yang kuat, menggunakan isyarat yang memberikan motivasi, dan memberikan penguatan positif karena pada dasarnya konsumen akan melakukan generalisasi terhadap suatu merek. Contohnya, konsumen yang pernah membeli komputer merek IBM yang mendapatkan pengalaman menyenangkan dan persepsi yang positif akan mengasumsikan bahwa merek IBM merupakan merek komputer yang terbaik, ketika konsumen akan membeli printer merek IBM mungkin konsumen juga berasumsi hal yang sama bahwa IBM menghasilkan printer yang baik. d). Keyakinan dan sikap; Melalui betindak dan belajar, orang mendapatkan keyakinan dan sikap. Keduanya kemudian mempengaruhi perilaku pembelian konsumen . Keyakinan dapat diartikan sebagai gambaran pemikiran seseorang tentang gambaran sesuatu. Keyakinan orang tentang produk atau merek akan mempengaruhi keputusan pembelian mereka. Contohnya studi tentang keyakinan merek yang menemukan bahwa konsumen sama-sama menyukai Diet Coke dan Diet Pepsi ketika mencicipi keduanya dalam tanpa merek. Tetapi, ketika mencicipi Diet yang diberi tahu mereknya, konsumen memilih diet Coke 65\% dan Diet Pepsi 23\%. Dalam contoh 
tersebut dapat disimpulkan bahwa keyakinan akan merek dapat mempengaruhi keputusan pembelian konsumen. Selain keyakinan, sikap merupakan hal yang tidak kalah pentingnya. Sikap adalah evaluasi, perasaan emosi, dan kecenderungan tindakan yang menguntungkan atau tidak menguntungkan dan bertahan lama pada seseorang terhadap suatu objek atau gagasan tertentu. (Kreh, dalam Kotler 2003).

Indikator keputusan pembelian menurut Kotler (2003) ada empat indikator keputusan pembelian, yaitu: 1). Kemantapan pada sebuah produk. 2). Kebiasaan dalam membeli produk. 3). Memberikan rekomendasi kepada orang lain. 4). Melakukan pembelian ulang.

\section{Kualitas Produk}

Produk merupakan inti dari sebuah kegiatan pemasaran karena produk merupakan output atau hasil dari salah satu kegiatan atau aktivitas perusahaan yang dapat ditawarkan ke pasar sasaran untuk memenuhi kebutuhan dan keinginan konsumen. Pada dasarnya dalam membeli suatu produk, seorang konsumen tidak hanya membeli produk, akan tetapi konsumen juga membeli manfaat atau keunggulan yang dapat diperoleh dari produk yang dibelinya. Oleh karena itu, suatu produk harus memiliki keunggulan dari produk-produk yang lain, salah satunya dari segi kualitas produk yang ditawarkan. Kualitas produk merupakan salah satu kunci persaingan diantara pelaku usaha yang ditawarkan kepada konsumen. Kotler dan Armstrong (2015) mendefinisikan kualitas produk sebagai berikut: "Product quality is the characteristics of a product or service that bear on its ability to satisfy stated or implied customer needs". Berdasarkan definisi tersebut dapat diketahui bahwa kualitas produk merupakan kemampuan suatu produk dalam memenuhi keinginan konsumen. Keinginan konsumen tersebut diantaranya daya tahan produk, keandalan produk, kemudahan pemakaian, serta atribut bernilai lainnya yang bebas dari kekurangan dan kerusakan.

Pada dasarnya kualitas mengandung banyak definisi karena setiap individu pasti memiliki cara pandang yang berbeda-beda. Perspektif kualitas produk merupakan persepsi seorang konsumen terhadap keseluruhan kualitas atau keunggulan suatu produk atau jasa dengan maksud yang diharapkan atau diinginkan oleh konsumen. Menurut Garvin yang dikutip Tjiptono dan Chandra (2016), perspektif kualitas dapat diklasifikasikan dalam lima kelompok sebagai berikut: 1). Transcendental Approach; Kualitas dalam pendekatan ini dapat dirasakan atau diketahui tetapi sulit didefinisikan dan dioperasionalkan. Sudut pandang ini biasanya diterapkan dalam seni musik, drama, seni tari, dan seni rupa. Selain perusahaan dapat mempromosikan produknya dengan pertanyaan-pertanyaan seperti tempat berbelanja yang menyenangkan (supermarket), elegan (Produk), kecantikan wajah (kosmetik) kelembutan dan kehalusan kulit (sabun mandi), dan lain-lain. Dengan demikian fungsi perencanaan, produksi, dan pelayanan suatu perusahaan sulit sekali menggunakan definisi ini sebagai dasar manajemen kualitas. 2). Product-based Approach; Pendekatan ini menganggap bahwa kualitas sebagai karakterisktik atau atribut yang dapat di kuantifikasikan dan dapat diukur. Perbedaan dalam kualitas mencerminkan perbedaan dalam jumlah beberapa unsur atau atribut yang dimiliki produk. Karena pandangan ini sangat objektif, maka tidak dapat menjelaskan perbedaan dalam selera, kebutuhan, dan preferensi individual. 3). User-based Approach; Pendekatan ini didasarkan pada pemikiran bahwa kualits tergantung pada orang yang memandangnya, dan produk yang paling memuaskan referensi seseorang (misalnya perceived quality) merupakan produk yang berkualitas yang 
paling tinggi. Perspektif yang subyektif dan demand-oriented juga menyatakan bahwa pelanggan yang berbeda memiliki kebutuhan dan keinginan yang berbeda pula, sehingga kualitas bagi seseorang adalah sama dengan kepuasan maksimum yang dirasakan. Kepuasan seseorang tentu akan berbeda-beda pula, begitu juga dengan pandangan seseorag terhadap kualitas suatu produk pasti akan berbedabeda pula pandangannya. Suatu produk yang dapat memenuhi keinginan dan kepuasan seseorang, belum tentu dapat memenuhi kepuasan orang lain. 4). Manufacturing-based Approach; Perspektif ini bersifat supply-based dan terutama memperhatikan praktik-praktik perekayasaan dan pemanufakturan, serta mendefinisikan kualitas sebagai sama dengan persyaratannya. Dalam sektor jasa, dapat dikatakan kualitas bersifat operation-driven. Pendekatan ini berfokus pada penyesuaian spesifikasi yang dikembangkan secara internal, yang sering kali di dorong oleh tujuan peningkatan produktivitas dan penekanan biaya. Jadi yang menentukan kualitas adalah standar-standar yang ditetapkan perusahaan, bukan konsumen yang menggunakannya. 5). Value-based Approach; Pendekatan ini memandang kualitas dari segi nilai dan harga dengan mempertimbangkan trade-off antara kinerja dan harga, kualitas didefinisikan sebagai "affordable excellence". Kualitas dalam perspektif ini bernilai relatif, sehingga produk yang memiliki kualitas paling tinggi belum tentu produk yang paling bernilai. Akan tetapi yang paling bernilai adalah produk atau jasa yang paling tepat dibeli.

Indikator kualitas produk menurut Nasution (2005) dimensi dari kualitas produk terbagi menjadi delapan yaitu performa, keistimewaan, kehandalan, kesesuaian dengan spesifikasi, daya tahan, kemampuan pelayanan, estetika, kualitas yang dipersepsikan.

\section{Promosi}

Menurut Kotler (2003), promosi merupakan berbagai kegiatan yang dilakukan antar perusahaan untuk mengkomunikasikan manfaat dari produknya dan untuk meyakinkan konsumen sasaran agar membelinya. Menurut Gitosudarmo (2000) menyatakan "promosi merupakan kegiatan yang di tujukan untuk mempengaruhi konsumen agar mereka menjadi kenal akan produk yang ditawarkan oleh perusahaan kepada mereka dan mereka menjadi senang lalu membeli produk itu", sedangkan menurut Babin (2011), promosi merupakan fungsi komunikasi dari perusahaan yang bertanggung jawab menginformasikan dan membujuk atau mengajak pembeli. Lupiyoadi (2001), menyatakan bahwa promosi merupakan suatu tindakan yang di dalamnya terdapat aktifitas periklanan (advertising), penjualan perorangan (personal selling), promosi penjualan (sales promotion), dan hubungan masyarakat (public relation).

Promosi di rancang semenarik mungkin untuk menjangkau masyarakat luas melalui bermacam - macam media, hal ini bertujuan agar perusahaan dapat berkomunikasi dengan konsumen. Tujuan promosi secara sederhana menurut Kuncoro (2010) terbagi menjadi tiga jenis yaitu: 1). Memberikan informasi pelanggan tentang produk atau fitur baru. 2). Mengingatkan pelanggan tentang merek perusahaan. 3). Mempengaruhi pelanggan untuk membeli.

Indikator Promosi menurut Kotler dan Keller (2012) terdiri dari: 1 ). Periklanan. 2). Promosi penjualan. 3). Penjualan perorangan. 4). Hubungan masyarakat. 5). Pemasaran langsung.

\section{METODE PENELITIAN}

\section{Rancangan Penelitian}

Tujuan penelitian ini adalah untuk menganalisis pengaruh kualitas produk dan promosi terhadap keputusan 
pembelian pelanggan produk PT. Sayap Mas Utama data yang digunakan dalam penelitian ini adalah data primer, yaitu berupa kuesioner yang disebar kepada pelanggan produk PT. Sayap Mas Utama di kota Bekasi sebagai responden. Alat analisis data yang digunakan dalam penelitian ini adalah analisis deskriptif, regresi linear sedehana dan regresi linear berganda.

Populasi yang digunakan dalam penelitian ini adalah para pelanggan yang berdomisili di wilayah Kota Bekasi yang jumlah tidak diketahui.

Metode pemilihan sampel dalam penelitian ini adalah metode pemilihan sampel nonprobabilitas (non-probability sampling method), yaitu dengan menggunakan pemilihan sampel berdasarkan tujuan (purposive sampling). Pemilihan sampel berdasarkan tujuan dipilih karena sampel yang diambil memiliki karakteristik tertentu, antara lain: Usia diatas 17 belas dan telah memenuhi minimal 1 kali.

\section{HASIL PENELITIAN DAN PEMBAHASAN}

\section{Hasil Penelitian}

\section{Uji instrumen data}

Berdasarkan uraian tersebut, maka untuk dapat menentukan apakah variabel kualitas produk dan promosi dapat dijadikan pengukur terhadap keputusan pembelian pelanggan produk PT. Sayap Mas Utama. Namun sebelumnya data diolah terlebih dahulu dan dilakukan pengujian terhadap varibel yang digunakan yaitu kualitas produk, promosi dan keputusan pembelian untuk mengetahui data tersebut akurat dan dapat dipercaya.

\section{Uji validitas}

Pengujian validitas ini dilakukan untuk menguji apakah tiap butir pernyataan telah mewakili indikator yang akan diteliti, Menurut Ridwan dan Sunarto (2011), menyatakan bahwa syarat minimum dikatakan valid apabila $r=0,27$. Uji validitas ini dapat dilihat dengan melihat korelasi antar nilai atau skor masing - masing butir pertanyaan dengan nilai total.

Dari perhitungan koefisien korelasi skor tiap butir pernyataan dari 100 responden tentang instrumen kualitas produk, dengan jumlah 9 butir pernyataan; instrumen promosi 15 butir pernyataan dan instrumen keputusan pembelian 9 butir pernyataan dengan total skor setiap responden diperoleh hasil $\mathrm{r}$ hitung lebih besar dari $\mathrm{r}$ tabel $=0,27$, maka seluruh item pernyataan didapatkan hasil yang valid.

\section{Uji reliabilitas}

Uji reliabilitas ini merupakan alat ukur yang menguji pengukuan secara konsisten. Pengujian ini dilakukan dengan membandigkan nilai atau skor cronbach alpha dengan nilai 0,60. Cronbach alpha harus lebih besar dari 0,60 baru dapat dikatakan reliabel.

Tabel 1: Hasil Uji Reliabilitas

\begin{tabular}{lccc}
\hline \multicolumn{1}{c}{ Variabel } & $\begin{array}{c}\text { Cronbach } \\
\text { Alpha }\end{array}$ & Nilai Kritis & Keterangan \\
\hline Kualitas Produk & 0,835 & 0,600 & Reliabel \\
Promosi & 0,842 & 0,600 & Reliabel \\
Keputusan Pembelian & 0,753 & 0,600 & Reliabel \\
\hline
\end{tabular}


Sumber : Data primer, diolah tahun 2020

Berdasarkan Tabel 1, promosi dan keputusan pembelian adalah menunjukkan bahwa kualitas produk, reliabel

\section{Analisis regresi linear sederhana}

Tabel 2: Pengaruh Kualitas Produk Terhadap Keputusan Pembelian

\begin{tabular}{lccccc}
\hline \multirow{2}{*}{ Variabel } & \multicolumn{6}{c}{ Parameter } \\
\cline { 2 - 6 } & Square & Konstanta & $\begin{array}{c}\text { Koefisien } \\
\text { Regresi }\end{array}$ & Sig & $\boldsymbol{\alpha}$ \\
\hline Kualitas Produk & 0,544 & 21,556 & 1,212 & 0,000 & 0,01 \\
\hline Pengujian Signifikan & & & & & \\
\hline t hitung = 10,630 & & & & \\
\hline $\begin{array}{l}\text { Keterangan: Variabel Keputusan Pembelian } \\
\text { Sumber: data diolah 2020 }\end{array}$
\end{tabular}

Berdasarkan Tabel 2, persamaan regresi linier sederhana sebagai berikut:

$$
\mathrm{Y}=21,556+1,212 \mathrm{X}_{1}
$$

Koefisien determinasi $\left(R^{2}\right)$ sebesar 0,544, artinya kontribusi kualitas produk kepada keputusan pembelian sebesar $54,4 \%$, sedangkan sisanya sebesar $45,6 \%$ disumbangkan oleh variabel lain, seperti promosi, dan lain-lain. Kualitas produk berpengaruh positif dan signifikan terhadap keputusan pembelian. Koefisien regresi kualitas produk bertanda positif sebesar 1,212, artinya jika kualitas produk meningkat, maka keputusan pembelian akan lebih baik. Jadi apabila semakin tinggi kualitas produk, maka semakin baik pula keputusan pembelian yang diambil oleh pelanggan.

Tabel 3: Pengaruh Promosi Terhadap Keputusan Pembelian

\begin{tabular}{lccccc}
\hline \multirow{2}{*}{ Variabel } & $\mathbf{R}$ & Parameter & \\
\cline { 2 - 6 } & Square & Konstanta & $\begin{array}{c}\text { Koefisien } \\
\text { Regresi }\end{array}$ & Sig & $\boldsymbol{\alpha}$ \\
\hline Promosi & 0,378 & 32,648 & 1,412 & 0,000 & 0,01 \\
\hline Pengujian Signifikan & & & & & \\
\hline t hitung $=10,720$ & & & & & \\
\hline
\end{tabular}

Keterangan: Variabel Keputusan Pembelian

Sumber: data diolah 2020

Berdasarkan Tabel 3, persamaan regresi linier sederhana sebagai berikut :

$$
\mathrm{Y}=32,648+1,412 \mathrm{X}_{2}
$$

Koefisien determinasi $\left(R^{2}\right)$ sebesar 0,678 , artinya kontribusi promosi kepada keputusan pembelian sebesar $67,8 \%$, sedangkan sisanya sebesar $32,2 \%$ disumbangkan oleh variabel lain, seperti kualitas produk, dan lain-lain. Promosi berpengaruh positif dan signifikan terhadap keputusan pembelian. Koefisien regresi promosi bertanda positif sebesar 1,412 , artinya jika promosi meningkat, maka keputusan pembelian akan lebih baik sebesar 1,412 kali atau sebaliknya. Jadi apabila semakin banyaki promosi, maka semakin baik pula keputusan pembelian yang diambil oleh pelanggan. 


\section{Analisis regresi linear berganda}

Tabel 4: Pengaruh Kualitas Produk dan Promosi Terhadap Keputusan Pembelian

\begin{tabular}{lccccc}
\hline \multirow{2}{*}{ Variabel } & $\mathbf{6}$ & Parameter \\
\cline { 2 - 6 } & Square & Konstanta & $\begin{array}{c}\text { Koef. } \\
\text { Regresi }\end{array}$ & Sig. & $\boldsymbol{\alpha}$ \\
\hline $\begin{array}{l}\text { Kualitas Produk } \\
\text { Promosi }\end{array}$ & 0,742 & 21,375 & $\begin{array}{r}0,967 \\
1,076\end{array}$ & $\begin{array}{l}0,000 \\
0,000\end{array}$ & 0,01 \\
\hline
\end{tabular}

\begin{tabular}{l}
\hline Pengujian Signifikan \\
\hline F hitung = 101,114 \\
\hline Keterangan: Variabel Keputusan Pembelian \\
Sumber: data diolah 2020
\end{tabular}

Berdasarkan Tabel 4, nilai F-hitung sebesar 101,114, artinya kualitas produk dan promosi secara bersama-sama berpengaruh signifikan terhadap keputusan pembelian. Koefisien determinasi $\left(R^{2}\right)$ sebesar 0,742 , artinya kontribusi kualitas produk dan promosi kepada keputusan pembelian sebesar $74,2 \%$, sedangkan sisanya sebesar $25,8 \%$ disumbangkan oleh variabel lain, seperti harga, dan lain-lain.

Persamaan regresi linier berganda sebagai berikut:

$$
Y=21,375+0,967 X_{1}+1,076 X_{2}
$$

Kualitas produk berpengaruh positif dan signifikan terhadap keputusan pembelian. Koefisien regresi kualitas produk bertanda positif sebesar 0,967, artinya jika kualitas produk meningkat, maka keputusan pembelian akan lebih baik atau sebaliknya dengan asumsi promosi konstan. Promosi berpengaruh positif dan signifikan terhadap keputusan pembelian. Koefisien regresi promosi bertanda positif sebesar 1,076, artinya jika promosi meningkat, maka keputusan pembelian akan lebih baik atau sebaliknya dengan asumsi kualitas produk konstan.

\section{Pembahasan}

Pengaruh Kualitas Produk Terhadap Keputusan Pembelian Produk PT. Sayap Mas Utama

Berdasarkan hasil penelitian menunjukkan bahwa kualitas produk mendukung perbaikan keputusan pembelian melalui kesesuaian dengan spesifikasi, keistimewaan, estetika, dan kemampuan layanan. Kesesuaian dengan spesifikasi yang dimaksud disini semacam janji yang harus dipenuhi oleh produk. Dimana produk tersebut diciptakan sudah sesuai dengan standarnya, PT. Sayap Mas Utama memenuhi standar kebutuhan atau keinginan pelanggan dalam penyediaan produk di kelasnya. Keistimewaan yang dimaksud adalah tingkat kelengkapan atribut-atribut yang ada pada sebuah produk. Suspensi yang kokoh dan ruang kabin yang lapang dari menjadikan salah satu alasan dalam pengambilan keputusan pelanggan membeli PT. Sayap Mas Utama. Estetika yang dimaksud, yaitu keindahan produk terhadap panca indera seperti desain, bentuk dan warna. Desain kemasan, varian dan keseluruhan produk PT. Sayap Mas Utama dapat menjadi salah satu faktor pengambilan keputusan pelanggan. Kemampuan layanan yang dimaksud meliputi kecepatan terhadap penanganan keluhan pelanggan, sehingga pelanggantidak merasa dirugikan. Dalam penelitian ini, indikator kualitas produk yang paling besar pengaruh nya terhadap keputusan pembelian ialah estetika dan kemampuan layanan. Hasil penelitian ini 
sesuai dengan hasil penelitian yang dilakukan oleh Saragih (2018) dan Juhana (2018).

\section{Pengaruh Promosi Terhadap Keputusan Pembelian Produk PT. Sayap Mas Utama}

Berdasarkan hasil penelitian menunjukkan bahwa promosi mendukung perbaikan keputusan pembelian pelanggan produk PT. Sayap Mas Utama melalui periklanan, promosi penjualan, penjualan perorangan, hubungan masyarakat, dan pemasaran langsung. Periklanan yang dimaksud adalah bentuk presentasi dan promosi non personal, mencakup broadcast, print, internet, dan lainnya yang dapat meningkatkan penjualan produk PT. Sayap Mas Utama. Melalui media sosial. Promosi penjualan yaitu insentif-insentif jangka pendek untuk mendorong pembelian atau penjualan suatu produk atau jasa, mencakup diskon dan kupon hadiah atau gimmick yang dapat meningkatkan minat pelanggan dalam keputusan pembelian produk PT. Sayap Mas Utama. Penjualan perorangan yang dimaksud berupa presentasi personal oleh tenaga penjual dengan tujuan menghasilkan penjualan dan membangun hubungan dengan pelangggan produk PT. Sayap Mas Utama. Hubungan masyarakat yang dimaksud yaitu membangun hubungan baik dengan pelanggan produk PT. Sayap Mas Utama agar memperoleh publisitas yang menguntungkan, ini mencakup special event sepeti di JIEXPO. Pemasaran langsung yaitu hubungan langsung dengan sasaran pelanggan bertujuan untuk memperoleh tanggapan segera dan membina hubungan yang baik dengan pelanggan mobil produk PT. Sayap Mas Utama. Dalam penelitian ini, indikator yang memiliki pengaruh paling besar terhadap keputusan pembelian ialah periklanan. Hasil penelitian ini sesuai dengan hasil penelitian yang dilakukan oleh Darmawan (2018), Fetrizen dan Aziz (2019).

\section{Pengaruh Kualitas Produk dan Promosi Terhadap Keputusan Pembelian Produk PT. Sayap Mas Utama}

Berdasarkan hasil penelitian menunjukkan bahwa kualitas produk dan promosi mendukung perbaikan keputusan pembelian produk PT. Sayap Mas Utama. Hasil penelitian ini sesuai dengan hasil penelitian yang dilakukan oleh Saragih (2018), Juhana (2018), Darmawan (2018), dan Fetrizen dan Aziz (2019).

\section{KESIMPULAN DAN SARAN}

\section{Kesimpulan}

Berdasarkan analisis deskriptif diperoleh: 1). Kualitas produk; Indikator kesesuaian terhadap spesifikasi, keistimewaan, estetika, dan kemampuan pelayanan membentuk kualitas produk. Indikator terbesar yang mendukung kualitas produk PT. Sayap Mas Utama, yaitu estetika dan kemampuan layanan, dimana tanggapan pelanggan mengenai desain dan kecepatan respon kepada pelanggan produk PT. Sayap Mas Utama. 2). Promosi; Indikator periklanan, promosi penjualan, penjualan perorangan, hubungan masyarakat, dan pemasaran langsung membentuk promosi. Indikator terbesar yang mendukung promosi produk PT. Sayap Mas Utama yaitu periklanan, dimana tanggapan pelanggan pada tersebar nya iklan dan penayangan iklan pada media elektronik.

$3)$.

Keputusan pembelian; Indikator kemantapan pada sebuah produk, kebiasaan dalam membeli produk, melakukan pembelian ulang, memberikan rekomendasi kepada orang lain membentuk keputusan pembelian. Indikator terbesar yang mendukung keputusan pembelian, yaitu kemantapan pada sebuah produk, dimana tanggapan pelanggan terhadap keyakinan dalam 
pembelian produk PT. Sayap Mas Utama. 4). Kualitas produk dan promosi mendukung perbaikan keputusan pembelian produk PT. Sayap Mas Utama.

\section{Saran}

Adapun saran-saran yang dapat penulis kemukakan yaitu sebagai berikut: 1). Bagi pengembangan ilmu; Dalam pengembangan ilmu manajemen pemasaran, saat ini sangat diperlukan skill yang mendukung pada tenaga pemasar. Hal ini dikarenakan semakin banyak perusahaan berlomba-lomba dalam memasarkan produk nya agar cepat laku di pasaran. Oleh karena itu perlu adanya pengembangan skill bagi para tenaga pemasar dalam memasarkan produk pada perusahaan. Pengembangan skill ini dapat dilakukan dengan cara banyak membaca referensi bertema bagaimana cara memasarkan produk di pasaran. Sehingga diharapkan semakin banyak juga yang bersedia berbagi pengalaman dalam kecakapan memasarkan sebuah produk. 2). Bagi penelitian selanjutnya; Dapat menjadi bahan pertimbangan untuk peneliti selanjutnya agar tidak hanya fokus pada variabel yang ada dipenelitian ini namun perlunya menambahkan variabel yang tidak diteliti pada penelitian ini seperti citra merek, kepuasan pelanggan atau yang lainnya supaya peneliti memperoleh hasil penelitian yang lebih akurat dan maksimal. 3). Bagi perusahaan Pimpinan PT. Sayap Mas Utama: a). Kualitas produk; Saat ini perusahaan berlomba-lomba dalam memasarkan produk. Dilihat dari hasil penelitian ini inidkasi kelemahan variabel terdapat pada indikator kesesuaian terhadap spesifikasi. Hal ini dapat menjadi evaluasi untuk perusahaan dalam peningkatan performa mesin pada Mitsubishi Xpander agar dapat bersaing di pasaran. b). Promosi; Dari hasil penelitian dapat dilihat indikasi kelemahan yang terdapat pada variabel promosi terdapat pada indikator promosi penjualan. Hal ini dapat menjadi evaluasi pada perusahaan untuk meningkatkan skill dalam penyampaian informasi dari tenaga pemasar ke pelanggan. Selain itu, pemberian hadiah dan diskon juga dinyatakan dapat mendukung promosi. Oleh karena itu, perusahaan di sarankan agar melakukan perhitungan kembali terkait dengan diskon dan juga hadiahhadiah yang akan diberikan kepada pelanggan. c). Keputusan pembelian; Dari hasil penelitian dapat dilihat indikasi kelemahan yang terdapat pada variabel keputusan pembelian terdapat pada indikator memberikan rekomendasi kepada orang lain. Hal ini dapat menjadi evaluasi bagi perusahaan untuk dapat menjadikan produk nya sebuah rekomendasi atau anjuran bagi pelanggan ke pelanggan lainnya. Salah satunya dengan cara meningkatkan kualitas produk dan promosi agar menarik pelanggan untuk melakukan keputusan pembelian.

\section{DAFTAR PUSTAKA}

Babin, 2011. Menjelajahi Riset Pemasaran. Jakarta: Penerbit Salemba Empat.

Basu, Swastha, Hani, Handoko. 2011. Manajemen Pemasaran-Analisis Perilaku. Konsumen. Yogyakarta : BPFE.

Darmawan, Muhammad Dodi. 2018. The Effect Of Price, Product Quality, Promotion, Social Factor, Brand Image On Purchase Decision Process Of Loop Product On Youth Segment (Case Study Of PT Telekomunikasi Selular). Jurnal International Seminar \& Conference on Learning Organization.

Fetrizen dan Aziz .2019. Pengaruh Kualitas Produk, Persepsi Harga dan Promosi Terhadap Keputusan Pembelian Paketan Data Internet Three (3) (Studi Kasus Pada Konter 
Bintang Cell Sidoarjo). Jurnal Sekolah Tinggi Ilmu Ekonomi KBP. Gitosudarmono, Indriyo. 2000. Manajemen Pemasaran. Edisi II. Yogyakarta: BPFE.

Juhana, Dudung. 2018. Pengaruh Kualitas Produk dan Promosi Terhadap Keputusan Pembelian. Jurnal Ekonomi, Bisnis \& Entrepreneurship.

Kotler, Philip. 2003. Manajemen Pemasaran. Edisi kesebelas, Jakarta: Indeks Kelompok Gramedia.

Kotler, Philip and Gary Armstrong. 2015. Prinsip-prinsip Pemasaran. Edisi 13. Jilid 1. Jakarta: Erlangga.

Kotler, Philip and Kevin Lane Keller. 2012. Marketing Management 13. New Jersey: Pearson Prentice Hall, Inc.

Kuncoro, Mudrajad. 2010. Dasar-Dasar Ekonomika Pembangunan, Yogyakarta: UPP STIM YKPN.
Lupiyoadi (2001) Manajemen Pemasaran Jasa Teori dan Praktek, Jakarata: Salemba Empat.

Nasution, M. N., 2005. Manajemen Mutu Terpadu: Total Quality Management, Edisi Kedua. Bogor: Ghalia Indonesia.

Riduwan dan Sunarto. (2011). Pengantar Statistika Untuk Penelitian Pendidikan, Sosial, Ekonomi, Komunikasi, dan Bisnis. Cetakan Ke-4 Bandung: Alfabeta.

Saragih, Bongsu. 2018. Pengaruh Kualitas Produk Dan Promosi Terhadap Keputusan Pembelian. Jurnal Manajemen Bisnis Krisnadwipayana.

Tjiptono, Fandy. 1997, Strategi Pemasaran, Edisi 1. Yogyakarta: Penerbit Andi.

Fandy Tjiptono dan Gregorius chandra. 2016. Service, Quality \& satisfaction. Yogyakarta: Andi. 